(C) Г.С. Поповкина

\title{
БОЛЕЗНЬ В ЖИЗНЕННОМ МИРЕ ПОДРОСТКА: ПО МАТЕРИАЛАМ РАССКАЗОВ Ю. КУЗНЕЦОВОЙ И Н. НАЗАРКИНА
}

В статье исследуется актуальная для медико-антропологического направления проблема жизненного мира больных детей, их представлений о болезни и её осознания. В качестве источника привлечень литературные произведения, в которых очень точно изображены больничные будни и переживание их детьми и тонко описаны не только настроение и характер героев, но и сам мир болезни, в котором оказались дети. С помощью феноменолого-герменевтического подхода осуществлена экспликация смыслового горизонта феномена болезни и связанных с нею феноменов жизни и смерти. Выяснено, что болезнь, ограничивая подростков в жизненных возможностях, делает их изобретательныли, чуткими, рассудительными, требовательными к себе и окружающим, заставляет раньще взрослеть. Болеющие дети обострённо чувствуют несправедливость болезни и смерти, ощущуают хрупкость жизни. Внимание и помощь родителей помогают им ненадолго забыть о своём болезненном состоянии. Проведенное исследование является первым шагом в изучении феномена болезни в жизненном мире детей. Полноценное раскрытие этого феномена требует дополнения литературных источников полевым материалом. Однако необходимо учитывать, что болеющие дети - особые информанты со специифическим положением, что делает сбор полевого материала сложной, а иногда - невыполнимой задачей, в связи с чем талантливо написанные литературные произведения по данной теме заслужсивают дальнейтего исследования.

Ключевые слова: жизненный мир, болезнь, здоровье, подростки, литературнье произведения

Ссылка при цитировании: Поповкина Г.С. Болезнь в жизненном мире подростка: по материалам рассказов Ю. Кузнецовой и Н. Назаркина // Вестник антропологии, 2022. № 1. С. 208-221.

DOI: $10.33876 / 2311-0546 / 2022-1 / 208-221$

(C) G.S. Popovkina

\section{ILLNESS IN THE LIFE-WORLD OF A TEENAGER: A STUDY BASED ON STORIES BY Y. KUZNETSOVA AND N. NAZARKIN}

The article examines the life-world of sick children, their ideas about the disease, and their awareness of it, which is relevant for medical and anthropological

Поповкина Галина Сергеевна - к.и.н., старший научный сотрудник, Институт истории, археологии и этнографии народов Дальнего Востока ДВО РАН (690001 Россия, г. Владивосток, ул. Пушкинская, 89). Эл. почта: galina.popovkina@gmail.com ORCID: 0000-0001-6521-8658 
science. The study is based on literary works, which accurately depict hospital life and children's experience and insightfully describe the mood and character of the characters and the world of the illness itself. The phenomenological-hermeneutic approach is used to explain the semantic horizon of the phenomenon of illness and the phenomena of life and death associated with it. It was found that the disease, while limiting adolescents in life opportunities, makes them inventive, sensitive, reasonable, demanding of themselves and those around them, encouraging them to grow up earlier. Sick children sharply feel the injustice of illness and death and sense the fragility of life. Parents' attention helps them forget about their painful condition for a while. This study is the first step in studying the phenomenon of disease in the life-world of children. Full disclosure of this phenomenon requires supplementing literary sources along with field material. However, it should be borne in mind that sick children are special informants with a specific situation, which makes collecting field material a complex and sometimes impossible task, and therefore talentedly written literary works on this topic deserve further research.

Keywords: life world, illness, health, adolescents, literary works

For Citation: Popovkina, G.S. 2022. Illness in the Life-World of a Teenager: a Study based on Stories by Y. Kuznetsova and N. Nazarkin. Herald of Anthropology (Vestnik Antropologii) 1: 208-221.

Author Info: Popovkina, Galina S. - PhD (hist.), Senior Researcher, Institute of History, Archaeology and Ethnography of the Peoples of the Far-East Far Eastern Branch Russian Academy of Science (690001 Russia, Vladivostok, Pushkinskaya st., 89). E-mail: galina.popovkina@gmail.com ORCID: 0000-0001-6521-8658.

Всестороннее исследование вопросов здоровья и болезни детей, безусловно, актуально и заслуживает постоянного внимания. Огромный пласт в исследовании этой проблемы составляют собственно медицинские труды, посвященные различным аспектам лечения и профилактики заболеваний у детей. Большой интерес у ученых вызывают и социальные, психологические, философские и гендерные аспекты проблем здоровья и болезни (Туркина, Вербина 2019; Милюкова 2020; Грошев 2009; Орлова 2010; Тхостов, Нелюбина 2009; Паутова 2015; Баранов, Яковлева 2018; Бовина 2008). Также рассмотрены психологические особенности состояний здоровья и болезни у дошкольников и младших школьников (Арзуманян 2018; Казанская, Мещеряков 2018; Котова, Николаева 2010), подростков (Васильева 2010; Бовина, Дворянчиков и др. 2018). Вопросы детского здоровья и болезни становились предметом изысканий для этнографии в русле изучения народно-медицинских знаний, реже - как собственно этнокультурная проблема (Чернылиова 2012; Кириленко 2016). Однако здоровье и болезнь могут быть рассмотрены и как те самые жизненные смыслы, на важность исследования которых с привлечением методов социальной антропологии указал акад. В.А. Тишков, поскольку у человека есть «потребность в самих жизненных смыслах. А значит и есть потребность в их изучении» (Тищков 2011). В относительно новом для российской науки направлении - медицинской антропологии - уже предпринимались попытки освещения некоторых аспектов здоровья детей (Ермакова 2018; Михель 2016; Колдман 2019). Тем не менее, пока нет медико-антропологических трудов, посвященных пробле- 
мам болеющих детей среднего школьного и подросткового возраста, раскрывающих, каким образом в их сознании осмысляется болезнь, как она отражается на их социальных практиках, на осознании себя и т.п.

Для начала работ в этом направлении решено привлечь в качестве источника литературные произведения. Для анализа выбраны известные рассказы Юлии Кузнецовой «Выдуманный жучок» и Николая Назаркина «Изумрудная рыбка» о детях, страдающих тяжелыми или неизлечимыми заболеваниями и вынужденных проводить много времени в больнице. «Выдуманный жучок» написан мамой юной пациентки нейрохирургического отделения, а «Изумрудная рыбка» - самим болеющим мальчиком. Для исследования важно, что эти книги биографичны, больничные будни и переживание их детьми изображены очень точно, часто показывая незначительные, на первый взгляд, детали, которые тонко описывают не только настроение и характер героев, но и сам мир болезни, в котором оказались дети. На литературных сайтах об этих книгах преимущественно одобрительные отзывы: те, кто оказывался в подобной ситуации, сходятся во мнении о достоверном изображении больничной жизни и детских переживаний.

Поскольку планируется исследовать жизненный мир больных детей, их представления о болезни и её переживание, наиболее подходящим видится обращение к феноменолого-герменевтическому подходу, философские основания которого были сформулированы в трудах Э.Гуссерля и М.Шелера, а их антропологическое применение развито в работах А.Щюца и др. В виду того, что источником исследования выбраны литературные произведения, основанные на реальных ситуациях больничного быта, это дает исследователю возможность отнестись к ним как к нарративу информанта, а в некоторых случаях даже как к включенному наблюдению, поскольку в них разворачиваются внутренние переживания болезни детьми-частыми пациентами больниц. Таким образом, применяя к указанным источникам феноменолого-герменевтический подход, мы можем осуществить экспликацию смыслового горизонта такого феномена как болезнь и связанных с нею феноменов жизни и смерти.

Героини книги «Выдуманный жучок» - девочки Таша тринадцати лет и Аня четырнадцати лет. В «Изумрудной рыбке» главное действующее лицо - мальчик Коля Кашкин, ему и его друзьям около тринадцати лет. Этим детям приходится жить и взрослеть, проходя испытание болезнью, нередко неизлечимой и с неизвестными прогнозами на будущее. Существование ребят, с одной стороны, ограничено пространством и обществом больницы, с другой - это ограничение по-особому влияет на осмысление ребятами жизни и своего места в ней. Феномены болезни, жизни и смерти раскрываются в жизненном мире подростков, находящихся в больнице (другое время их жизни в рассказах не показано), с помощью описания болезни и связанных с ней пространства, людей и событий, окружающих детей и взрослых.

\section{Болезнь и связанные с ней пространство, люди, события}

В жизни тяжелобольных детей болезнь занимает очень много места. Таша вынуждена менять раз в четыре года шунт, встроенный в головной мозг; Аня ложится в больницу каждые четыре недели для прохождения химиотерапии. Коля Кашкин количество своих посещений больницы не считал и о болезни не рассказывал, в больнице у него есть друзья, которые попадают на лечение каждый в разное время, но 
так часто, что мальчики успевают друг друга запомнить и подружиться. Болезни как медицинское явление детьми не обсуждаются: «Дети не спрашивают о диагнозе» (Кузнецова 2011: 17). В рассказах много упоминаний больничных процедур: капельницы, уколы, прием лекарств, подготовка к операциям, нахождение в реанимации, в палате интенсивной терапии или в боксе на карантине. Часто присутствует описание неудобств, причиняемых болезненным состоянием: наружный шунт не дает «ни прогуляться, ни душ принять... до грязных волос не хочется дотрагиваться... а во рту почему-то всё время горько» (Кузнецова 2011: 62) и т.п., для Таши «хуже нет послеоперационных уколов» (Кузнецова 2011: 11), загипсованная нога мешает Коле свободно передвигаться, а удаление сразу двух зубов повлекло необходимость молочной диеты, включающей такой нелюбимый Колей творог; его друг на растяжке и буквально привязан к кровати, из-за чего невозможно вместе хоть как-то развеяться вне палаты, один из друзей Коли, а в другое время и он сам, может передвигаться только на коляске, что делает неосуществимым его участие в некоторых играх и т.д. (Назаркин 2018: 7-10, 81-181). Болезнь сковывает ребят, лишает многих занятий, свойственных их возрасту. Горько это осознается детьми, когда они сравнивают себя с другими. Так, в отделении общей хирургии «здоровые слонята по сравнению с нами, нейрохирургическими. Особенно с теми, кто худой от химиотерапии. Они носятся по коридору, прихрамывая или поддерживая забинтованные руки, катаются по очереди в инвалидных колясках и хохочут над гипсами. У нас в отделении никто не хохочет над проводками... Еще у них игровая комната... А мы даже спим с мамами, потому что коек не хватает. А они все равно нам завидуют...» (Кузнециова 2011: 15). По признанию Таши, в девять лет «начинает точить зависть» к здоровым одноклассникам (Кузнецова 2011: 9). Ребята невольно сравнивают свои возможности здоровья с возможностями здоровых людей, например, как хорошо просто ходить на здоровых ногах (Назаркин 2018: 117-119). Однако, несмотря на разницу в диагнозах, болезнь уравнивает детей, лишая их чего-то важного: дети из хирургического отделения завидуют нейрохирургическим, потому что те лежат с мамами. А нейрохирургические завидуют, потому что у них нет сил развлекаться так, как дети из общей хирургии.

Однако эти неудобства, хоть и сильно ограничивают жизнь ребят, не прерывают стремления детей жить полной жизнью: мальчики собрались убежать из больницы на рыбалку и взять с собой друга на коляске, Коля на костылях переходит в другой корпус для того, чтобы купить мороженое, юный ухажер Серый (10 лет) предлагает Ане уехать в Грецию, когда они выздоровеют, и т.П. Дети пытаются расширить скудный арсенал больничных развлечений: кроме чтения книг, разговоров по телефону или игры на планшете, придумывают новые способы занять себя. Из капельниц плетут различные поделки (Назаркин 2018: 18-23), занимаются вязанием, устраивают гонки на колясках (Назаркин 2018: 44), ходят в переход между корпусами, чтобы посмотреть в окна, которые «в переходе выходят на улицу... если стоять, прижавшись лбом к холодному стеклу, и пристально смотреть на машины, то можно немножко забыть, что ты в больнице» (Назаркин 2018: 13), пририсовывают на плакате «пожарникам шарики, банты и крылья» (Кузнецова 2011: 99) и т.п. Мама спрашивает Ташу: «И как у тебя получается радоваться жизни в больнице?... Я лично просто больше не могу» (Кузнецова 2011: 56). Стремление играть и смеяться свойственно и здоровым, и больным детям. По меткому наблюдению медсестры Тоси «да они вас сами с удовольствием посмешат... такие уж они дети. С ними не соскучишься» (Кузнецова 2011: 
78). Часто развлечения либо оканчиваются неудачей, либо вовсе срываются, их не доделывают: поход на рыбалку ребята проспали (Назаркин 2018: 7-11), походить по отделению скучно, посидеть на подоконнике у ординаторской тоже скучно - «за окном был вечер, двор пустой, неинтересный» (Назаркин 2018: 74), мороженое в буфете невкусное (Назаркин 2018: 72), плетеная рыбка получилась не того цвета, как ожидалось (Назаркин 2018: 23), новогодний розыгрыш оказался глупой шуткой (Кузнецова 2011: 65-83). Само наличие болезни делает полноценные забавы детей невозможными, отчасти потому, что в больнице «времени полно. Просто оно рваное какое-то... Кусочками. Потому что постоянно дёргают. То уколы, то осмотр, то на рентген, то обедать пора. Никакой личной жизни» (Назаркин 2018: 82). Порой, в развлечениях проскальзывает горечь от осознания своего положения: «В нашем отделении, кстати, любят игрушечный транспорт: малышня запускает в коридоре радиоуправляемые катера, ребята постарше собирают объёмные пазлы с истребителями. Словно все верят, что картонный и пластмассовый транспорт может увезти нас подальше отсюда» (Кузнецова 2011: 96). Дети хотят покинуть мир болезни: «...Когда-нибудь нарисованный робот возьмет нас с Аней и унесет туда, где нет уколов и запаха лекарств» (Кузнецова 2011: 104), но это всего лишь мечта, избавление от недуга сравнимо с чудом, оно очень призрачно и выглядит так же нереально, как нарисованный робот.

Болезнь заставляет ребят думать о своем состоянии, анализировать его и свою жизнь. Восприятие болезни меняется у детей по мере взросления. Так, Таша рассказывает о себе: «В 2 месяца ничего не помнишь, в три года - не соображаешь, что делают, а в 6 лет становится страшно, только что вроде узнаешь, что люди умирают. В 9 понимаешь, что это глупость. Но начинает точить зависть к здоровым одноклассникам. В 12-13 хочется всем рассказать, чтобы все испугались и поняли, что ты герой. Я привыкла уже, потому что пришлось пораньше: у меня мама - как ребенок» (Кузнецзова 2011: 9). Недуг делает из детей маленьких взрослых, которые рефлексируют о происходящем и терпеливо, разумно относятся к своему заболеванию: «Я никому не завидую и никому не хочу рассказывать свой секрет... Многим тяжелее... А теми, кто борется, и не сдается, я восхищаюсь» (Кузнецова 2011: 11), - думает Таша, а Коля считает: «Сегодня пляшем, завтра ляжем» (Назаркин 2018: 180), «Вчера скакал, а сегодня лежит. Чего тут такого-то? Мы все здесь такие. Ничего, все на седьмом побывали (на этом этаже находится реанимационное отделение - Г.П.) и пока вот скачем. Рыцарь должен уметь смотреть в глаза своей судьбе. Нормальная жизнь» (Назаркин 2018: 29).

Осознание своей болезни иногда приводит ребенка к бессильной злости, обиде на всех: «Я не хочу быть самой собой, а хочу быть кем-то другим.... Вот бы... всем отомстить за все!» (Кузнеццова 2011: 124). Однако это состояние дает импульс рассуждениям о своем месте в жизни, становится своего рода рубежом, с которого начинается новая страница бытия: «Но получалось, что я своего конца дожидаюсь, постоянно ноя и жалуясь на жизнь. Уборщица права - надо чем-то заниматься. Но чем-то хорошим, радостным. Не нытьём. Радостные дела дадут силы. Надо же, как просто. С чего начать?...» (Кузнецова 2011: 130).

Мысли о болезни влекут за собой раздумья о крови, о жизни и смерти. Собственная болезнь словно является толчком для раннего взросления и совсем недетских размышлений. Так, по мнению ребят, все постоянные пациенты больницы знают состав крови, ее объем в теле человека и т.д., «не путают лимфоциты с лейкоцитами, 
про факторы, про каскад знают. ... такие простые вещи, ну... все знают, в общем! Это же само если не с первого, то со второго попадания в больницу запоминается» (Назаркин 2018: 31-32). В то же время кровь в восприятии детей является той субстанцией, которую видеть не должно, она почти сакральна, запретна, ее вид заставляет замолчать и задуматься: «В другой раз мы бы засмеялись» (над вопросом мальчика про УЗИ - Г.П.), но «я вижу кровь, которая сочится сквозь простыню» (Кузнеиова 2011: 25).

Тяжелобольные дети очень рано видят смерть рядом с собой, ощущают хрупкость человеческой жизни, поэтому смерть тоже занимает важное место в их жизненном мире. Прежде всего, оценивается возможность собственной смерти. Например, Таша услышала вопрос мальчика отцу: «А умирать страшно, папа?», после чего и сама задумалась над этим вопросом. Страх смерти у Таши связан с заботой о матери, она решает, что умирать страшно: «Как это маму можно одну на белом свете оставить?» (Кузнецова 2011: 27)

Смерть видится чем-то страшным, неправильным, несправедливым. Понимание, что маленький Саня умирает, сначала поражает Ташу, вызывает в ней гнев, обиду, потом вдруг обжигает её, пробуждая теплые чувства к матери. Сосед Сани по палате, казалось бы, равнодушный и безучастный к чужой судьбе Максим, узнав о Саниной смерти, выбросил в окно свой компьютер, расплакался «громко, басом, за них двоих, за все отделение» (Кузнецова 2011: 39-43). Близость смерти является для подростка поводом осмыслить свою жизнь, определить своё дальнейшее поведение и отношение к себе и миру, свою жизненную стратегию. Как правило, эта стратегия основана на необходимости действовать быстро, пока жизнь не оборвалась: «Я же в спецшколе учусь (там учатся дети со слабым здоровьем - Г.П.) ..., а там все считают, что нужно всё делать сегодня, потому что завтрашнего дня может и не быть», - говорит Аня. Но со временем к девочке приходит очень мудрое понимание жизни: «Я не считаю, что надо успеть всё сегодня переделать. Жизнь похожа на вязание. Если вяжешь спокойно, будет красивая вещь. А если торопишься и пропускаешь петли, получится неровно и с дырками» (Кузнецова 2011: 52-53). Таким образом, смерть видится детям как событие страшное, непоправимое, ошибочное, но она же учит их рассуждать о жизни, вырабатывать собственное отношение к жизни и смерти и существовать в соответствии со своими убеждениями.

Мир собственных переживаний больного ребенка тесно связан с его восприятием больничного окружения. Обстановка вокруг детей нерадостная, неприятная. Больничный корпус видится замком злого волшебника «тухлого розового цвета» (Кузнецова 2011: 134), в палатах - уныло и темно, по выражению их обитателей, «глаза сломать можно»: «Лампочка в интенсивке слабенькая, еле горит... Утро зимнее и так тёмное, а у нас в палате с мутными окнами как будто всё время ночь...» (Кузнец ова 2011: 62). Днем раздражает «свет верхних сине-белых ламп», а ночью на потолке отражается синий свет фонаря, который наводит тоску. Ребята решают, что у них дома не будет ни одной синей лампочки (Назаркин 2018: 78). Обстановка коррелирует с настроением: «Я, наверное, хорошо выгляжу. Особенно на унылом фоне унитазов и баков с надписью “1-е нейрохирург”. Впрочем, на душе у меня было так же отвратительно» (Кузнецова 2011: 129). Дополнительный дискомфорт приносят неудобные кровати. Кроме того, однообразная еда, когда заранее известно повторяющееся меню на много дней вперед, может быть и неприятной, например, остывшей; героям 
рассказов везет, если развозить обед начинают с их палаты, «значит, каша не до конца холодная» (Назаркин 2018: 65, 92). Двор больницы навевает скуку: «Все окна нашего корпуса выходят во двор. А что может быть интересного в больничном дворе» (Назаркин 2018: 13). Больничное окружение видится детям безрадостным, скучным, унылым. Раскрасить его можно только с помощью своей фантазии. Когда ребятам довелось идти вместе с медсестрой по подвалу, они с удовольствием сочиняли небылицы про секретную военную краску, секретные провода до «самых главных» ракет, про секретную лабораторию и про специальную еду (Назаркин 2018: 49-52). Чтобы скрасить новогодний вечер, который они вынуждены проводить в больнице, Таша и Аня представляют себя древнегреческими богинями (Кузнецова 2011: 66-67), а Коля Кашкин - оказавшимся на необитаемом острове (Назаркин 2018: 174-175). Во время таких игр детям приходит горькое осознание своего одиночества: «... никто из них не придёт. Потому что они там. А мы - тут. Такова судьба» (Назаркин 2018: 174). Таким образом, обстановка больницы усугубляет мрачное восприятие болезни детьми, которые, хоть и понимают свое печальное положение, тем не менее, стараются придать красок жизни, придумывая разнообразные фантастические истории про себя самих и своё окружение.

Важной составляющей в проживании болезни ребенком становится медицинский персонал. Медсестрам приходится выполнять множество назначений, данных врачами, и проводить таким образом время с детьми. В восприятии детей медсестры разные. Хорошие - те, которые занимаются только процедурами и не вникают в особенности поведения детей, не пытаются их воспитывать, дают послабления в больничном режиме: «Елена Львовна ... процедурная сестра, уколы там всякие делает, капельницы, а за нами не следит. Если бы все взрослые были такими» (Назаркин 2018: 57). Хорошая медсестра, как например, старенькая Тося, помнит всех пациентов, которые неоднократно бывают в отделении (Кузнецова 2011: 30), много и старательно работает. Такие медсестры спят на жестких неудобных скамейках у палаты интенсивной терапии и не уходят спать на свободные мягкие койки (Кузнецова 2011: 46). С ними детям легче живётся: «Хорошо, всё-таки, когда медсёстры ведут себя как люди, а не как медсёстры!» (Назаркин 2018: 82) или «Она ничего так медсестра, вредная, конечно, но понимающая» (Назаркин 2018: 165). Вредные медсестры ленивы, а иногда еще и злы, не уважают старших коллег (Кузнецова 2011: 45-46), чересчур строго следят за детьми: «Лина Петровна дежурит, она вредная, вечно норовит проверить» (Назаркин 2018: 9), а также «Лина Петровна или Катя Васильевна вмиг всё узнают» (Назаркин 2018: 13), не разрешают нарушать режим: «Катя Васильевна мой фонарик отобрала, чтобы маме отдать обратно» (Назаркин 2018: 78).

Врачи в глазах детей также подразделяются на хороших и плохих. Обобщённый портрет хорошего врача выглядит следующим образом. Хороший врач - профессионал высокого класса, как например, Игорь Маркович, на которого «пол-Москвы молится» (Кузнецова 2011: 24). Он заботливый, внимательный: «Игорь Маркович подкрался тихонько, чтобы не разбудить спящую медсестру. Бледный, не выспавшийся, в помятой, больше чем обычно, одежде, он открывает окошко и с наслаждением подставляет лицо под ветерок» (Кузнецова 2011: 28), самоотверженный: анестезиолог Виктор Евгеньевич во время перерыва «снял маску, шапочку, вытер лоб салфеткой, нацепил все обратно и пошёл в операционную», даже есть не стал (Кузнецова 2011: 30). Хороший врач бывает и строгим: заведующий отделением «Андрей Юрьич - толстый, высокий 
и говорит громким голосом. Я бы на месте курильщиков... спрятался», а «после разговора с ним все мамы успокаиваются» (Назаркин 2018: 13, 170). Лечащий врач, как правило, хороший: «Василь Василич - . . о он ничего, веселый и понимающий» (Назаркин 2018: 49), «Давид Игоревич... самый классный врач... Ну, после моей Елены Николаевны, конечно... Ну и Андрей Юрьича» (Назаркин 2018: 101) или даже лучший: «... моя Елена Николаевна самая красивая докторша на нашем этаже. Из двух. И на пятом тоже. Хотя Валька Чуйков говорит, что его Ольга Константиновна красивее, но он ни фига не понимает. И вообще. А моя Елена Николаевна в маске и шапочке на космонавтских врачей из кино похожа... А у моей Елены Николаевны уши зато красивее. Вот» (Назаркин 2018: 62). Хороший врач обладает признаками героя («космонавтский врач» - особенная, почти героическая профессия) и похож на «самого лучшего, самого доброго волшебника на свете» (Кузнецова 2011: 141).

Плохой врач, напротив, глуп, непрофессионален, равнодушен, труслив. Таков Александр Степанович в рассказах «Выдуманный жучок»: он не участвует в спасении травмированного мальчика, предпочитая теплый плед, телевизор и банку с вареньем (Кузнецова 2011: 25), норовит обвинить в своих ошибках коллег (Кузнецова 2011: 61), ему не доверяют сложные случаи (Кузнецова 2011: 28). Иногда репутация «вредного» закрепляется за врачом без особых видимых причин, ввиду неприятного стечения обстоятельств: «Евгений Палыч ...самый вредный из врачей, это все знают!» (он закрыл за собой дверь ординаторской, когда ребята хотели подслушать разговоры врачей - Г.П.) (Назаркин 2018: 68).

Как видно из представленных рассказов, «хорошие» медицинские работники имеют в жизни детей и в их восприятии болезни более важное значение, чем «плохие». Описанию «хороших» врачей и сестер отводится гораздо больше внимания, выявляется больше причин для характеристики медработника как «хорошего». Однако у маленьких пациентов отчетливо ощущается страх оказаться в руках «плохого» врача, понимание, что от проведения операции зависит слишком многое: либо продление жизни и надежды, либо смерть или тяжелые последствия лечения. Само существование непрофессионалов и «плохих» кажется чем-то неправильным, что необходимо исправить. Для этого дети используют свои, доступные им, способы: «обезвреживают» злую медсестру Лидку с помощью куклы вуду (Кузнецова 2011: 45-51), прячут в шкафу Александра Степановича (Кузнецова 2011: 25-27). Думается, такие факты свершения «правосудия по-детски» не могли иметь место в реальной жизни, но совершенно очевидно, что «плохой» врач или сестра - один из главных страхов ребенка в больнице, от которого он хочет избавиться любым способом.

\section{Взрослые в жизни больного подростка}

Особая категория в окружении больных детей - взрослые (родители и посторонние). Прежде всего, внимание детей обращено на их матерей. Они словно не понимают, почему матери беспокоятся о них: «Мамы вечно хотят знать много всяких дурацких неважных вещей: что мы ели на завтрак...» (Назаркин 2018: 10). Им не нравится, что любимая тема «разговора мамаш» - диагноз ребенка (Кузнецова 2011: 17). Нередко мама в глазах ребенка предстает в детской роли: «Мама все слушает, что Андрей Юрьич говорит. Как маленькая, честное слово!» (Назаркин 2018: 34). Мамы нередко проявляют слабость: мама Таши «набирает для папы какие-то горестные эсэмэски» 
(Кузнецова 2011: 33), плачет перед операцией (Кузнецова 2011: 107, 109), способна расплакаться из-за незначительного повода, например, из-за того, что не успела в душ (Кузнецова 2011: 38), «хватает ртом воздух», когда узнала о неожиданной выписке (Кузнецова 2011: 138) и т.п. Болезнь детей давит на родителей, это видят и дети. Так, Таша заметила, что ее мама про шунт всегда говорит шепотом (Кузнецова 2011: 86). В такой ситуации дети берут на себя роль взрослого. Например, за мамой приходится присматривать: «А с этими мамами одни проблемы, да?» (Кузнецова 2011: 21), её нужно поддерживать и подбадривать: (повзрослеть) «пришлось пораньше: у меня мама - как ребенок. Мне приходится ее поддерживать. Ей очень тяжело» (Кузнецова 2011: 9), стараться проявлять внимание и заботу: «Слабые нервы у моей мамы» (Кузнецова 2011: 19), успокаивать (Кузнецова 2011: 33), ответственно относиться к подаркам: «Только я в него играть не хотел, я в самолеты хотел. А набор взял, потому что нельзя же маму огорчать. Она же старалась» (Назаркин 2018: 66-67). Матери других детей также надломлены, их силы уничтожает болезнь ребенка. Так, среди пациентов больницы была распространена примета, согласно которой нужно украсть в отделении пеленку, чтобы «больше туда не возвращаться». Действенность этой приметы решила испытать даже Мадина, которая знала, что «муж её убьет» за воровство: «Но как же пребывание в больнице подточило мусульманку Мадину, чтобы (она украла пеленку)» (Кузнецова 2011: 92-93). Таша «видит», как за Мадиной ползёт противный жучок отчаяния. Дети ощущают тоску, сопровождающую взрослых в больнице. Так, мамы разрисовывают раскраски, которые подарены детям: «ужасно... как они говорят друг другу, героически улыбаясь: "Ну что ж такого, что в новый год загремели, подумаешь! Конечно, всякое бывает!” А у самих в глазах тоска» (Кузнецова 2011: 66-67). Подобная маскировка чувств взрослыми воспринимается подростками с раздражением: «Ненавижу враньё» (Кузнецова 2011: 67).

Однако обремененные собственной болезнью дети нуждаются в поддержке и помощи, прежде всего, со стороны родителей. Они помнят, что «Мама и так должна быть сильной» (Кузнецова 2011: 38), могут на некоторое время забыть о своей взрослой роли: «Теперь я ныла, а мама меня утешала» (Кузнецова 2011: 133), способны загрустить, не увидев в группе других мам свою: «Голос у него нечастный. Мама не пришла. Конечно, карантин есть карантин, но прийти покричать с другими мамами она могла же ведь, правда?» (Назаркин 2018: 37). Родители остаются для детей опорой, которая дает надежду, что всё будет хорошо, например, потому что мама или папа помолятся за них. Тема молитвы периодически возникает в рассказах детей. Это всегда - надежда и успокоение: мама Таши молится, чтобы не стало хуже (Кузнецова 2011: 108), мама Ани после операции у дочери - бледная, но довольная, «в руках сжимает “акафистник”, толстую книгу с молитвами» (Кузнецова 2011: 33). А отец Толика, священник, не приносил передач, но молился и причащал сына (Кузнеиова 2011: 33). Такое поведение отца вызывало недоумение, а порой и возмущение некоторых родителей, но не болеющих подростков. «Все умеют молиться», - заключает Таша. Видимо, груз болезни настолько тяжел, что дети приучаются очень зорко видеть лучики надежды. Иногда дети сами придумывают ободряющие сигналы надежды: «Анька не успела довязать шарф. Значит, всё у всех только начинается» (Кузнецова 2011: 57).

Об отношениях с отцом говорится только в рассказах «Выдуманный жучок». В начале повествования отец Таши выглядит не вполне понимающим сложность ситуации, трудности больничного существования: он не делает неожиданных подарков, 
путает виды продуктов для передачи жене и дочери, по-деловому отвечает на телефонные сообщения. Однако по мере наблюдения за родителями детей в отделении, Таша меняет мнение о собственных. Для нее становится открытием, что другие родители тоже расстроены, потеряны, дезориентированы, не всегда ведут себя подходящим образом: муж Мадины кажется нехозяйственным (Кузнецова 2011: 93-94), папа «оручего» бестолково топчется в дверях отделения и т.п. (Кузнецова 2011: 99). Тем не менее, эти люди находят нужную линию поведения, могут придумать что-то, скрашивающее жизнь своих близких: супруг Мадины приносит пастилу (Кузнецова 2011: 103), папа «оручего» нарисовал на асфальте перед палатой робота и стал рисовать что-то новое каждый день, отчего ребенок больше не плакал при расставании с отцом (Кузнецова 2011: 101-102). Таша стала замечать грусть в глазах отца, поняла, что и ему тяжело (Кузнецова 2011: 105).

Болеющему ребенку важно ободрение со стороны родственников. Даже если не всегда получалось ладить, например, с сестрой (Кузнецова 2011: 136-140), свидание с ней, а тем более, подарки, способны поднять подростку настроение: «... всё-таки иногда сёстры что-то понимают, факт. Даже старшие» (Назаркин 2018: 112).

Взрослые вокруг болеющих детей нередко бывают неприятными, особенно если они стараются отгородиться от мира тяжело больных. Таковы были соседи Таши по палате, которые всячески подчеркивали, что в отделение попали только на обследование. У них было очень много еды, а «в лицах что-то бульдожье» (Кузнецова 2011: 32). Не понравилась девочкам и студентка актерского факультета, пришедшая играть роль Снегурочки, но признавшаяся другу: «Вот только ЭТИХ не люблю. У которых химия» (Кузнецова 2011: 71). Эти люди лгали сами себе, стараясь отгородиться от мира тяжелых болезней и детей, страдающих ими. Однако неприязнь к этим людям исчезает, как только те принимают существование сложных больных (Кузнецова 2011: 35-36, 78). Дети хотят правды: в эмоциях, отношениях, поведении взрослых. Взгляд подростков на неприятных людей меняется, как только взрослые начинают воспринимать их такими, какие они есть.

\section{Болеющие подростки и другие дети}

Герои рассказов - дети среднего и старшего возраста, подростки. У них по-разному складываются отношения друг с другом. Обычно дети - компаньоны в играх и развлечениях, вместе переживают ответственные моменты в своей жизни. Немаловажную роль в коммуникации детей играет шутка. Даже если объект подшучивания не разделяет общего веселья, смех важен для ребят как способ разнообразить будни или добиться желаемого результата: «Толик стал совсем глупый, потому что ему одна девчонка нравится. Ходит с глупыми глазами, по-дурацки как-то. Мы с Пашкой про него смеялись, а он обижается, говорит, что мы еще маленькие» (Назаркин 2018: 77) или «тут Серый увидел, что мы внутри смеемся, и замолчал. А то я уже хотел перестать с ним дружить, если он будет все время один разговаривать. А теперь я тоже мог разговаривать» (Назаркин 2018: 52). Приветствуется равенство возможностей, щедрость (Назаркин 2018: 70-72). Недопустимыми в поведении считаются жадность (Назаркин 2018: 24-29, 65-68), желание воспользоваться чужими идеями (Назаркин 2018: 34), особенно - слабость, нетерпение болезни: так, Коле, Толику и Серому не нравится, что стонет Тёпочкин. В рассказе дается много объяснений, 
почему не нравится, одно из них следующее: «И сочувствия у нас никакого нету, потому что мы ничего все равно сделать не можем. И незачем ему на нас стонать» (Назаркин 2018: 53-55). Подростки хоть и относятся к сверстникам доброжелательно, но не делают послабления, предъявляют «взрослые» требования, играют по отношению друг к другу взятую на себя «взрослую» роль.

В условиях больницы они взаимодействуют не только со своими ровесниками и взрослыми, но и маленькими детьми. В большинстве случаев малыши выступают фоном в рассказах подростков: то они пытаются развлечься с помощью игрушечного транспорта, то сами устраивают гонки на колясках, только «малышня всякая» ест какао и кашу и плетет фигурки из «сырой» капельницы (Назаркин 2018: 7, 9), «детки к постели своими капельницами привинчены, вот им и читают вслух сутками напролёт» (Кузнецьова 2011: 74). Иногда взрослые не могут найти подход к малышам, тогда на помощь приходят подростки. Такова история Степки-растрёпки, который боялся «всего в больнице» и только благодаря находчивости Таши и Ани, предложивших ему быть секретным агентом для обезвреживания злой медсестры Лидки, спокойно отправился на операцию (Кузнещова 2011: 47-51). Подругам жаль маленьких детей, попавших в больницу, но они думают, что крохи находятся в выигрышном по отношению к ним положении, потому что не понимают, что происходит. Полуторагодовалая соседка Таши по палате не понимает, что говорит её мать. «Как я ей завидую!» - подумала Таша однажды, - «я тоже не хочу ничего понимать» (Кузнецова 2011: 64), а Коля завидует «черно-белой завистью. В полосочку» беспечному малышу Славке (Назаркин 2018: 127). В рассматриваемых рассказах маленькие дети для старшихне только неотъемлемая часть больничных будней, но и повод задуматься о жизни, о месте в ней болезни и своём отношении к ней.

Таким образом, мы видим, что литературные произведения представляют собой ценный источник для медико-антропологического исследования, особенно с применением феноменолого-герменевтического подхода. Исследование феномена болезни в жизненном мире подростков показывает, что она лишает их обычных способов проживания жизни, ограничивает в возможностях обучения, развлечений и общения, в то же время делая их изобретательными, чуткими, рассудительными. Все происходящее в жизни ребят носит отпечаток болезни, больничной повседневности. Оказавшись в исключительной ситуации болезни и больницы, они вынуждены как-то обдумывать происходящее с ними; многие аспекты жизни требуют от ребят немедленного осмысления. Болезнь видится им чем-то неприятным, безрадостным, скучным, смерть - несправедливым, неправильным, жизнь - хрупкой. С болезнью и смертью связан самый тяжелый страх: боязнь «злых» и непрофессиональных медицинских работников, от которых зависит их жизнь, и страх самой смерти. Болезнь заставляет подростков рано становиться взрослыми: они чувствуют себя взрослыми, способными взять на себя ответственность за маленьких соседей по палате, друзей, своих уставших родителей. Болезненное состояние обостряет в детях чувство справедливости, правдивость, открытость, в некоторых случаях - жесткую требовательность к себе и окружающим. В то же время болезнь не способна окончательно стереть детство из жизни детей: ребятам необходимы детские развлечения, внимание и помощь именно родителей - в такие моменты они могут ненадолго забыть о бремени своего недуга. 
Конечно, все вышеизложенное можно считать лишь первым шагом в исследовании феномена болезни в жизненном мире детей. Очевидно, что полноценное раскрытие этого феномена требует дополнения литературных источников полевым материалом. Однако, учитывая особенность информантов и их специфическое положение, можно предположить, что сбор такого материала - непростая задача и талантливо написанные литературные произведения на данную тематику достойны дальнейшего исследования.

\section{Источники и материалы}

Кузнецова 2011 - Кузнецова Ю.Н. Выдуманный жучок. Рассказы о больничной жизни. М.: Центр Нарния, 2011. 160 с.

Назаркин 2018 - Назаркин Н.Н. Изумрудная рыбка. Мандариновые острова: Сборник рассказов. М.: Эгмонт Россия Лтд., 2018. 184 с.

\section{Научная литература}

Арзуманян О.В. Представления школьников о здоровье и болезни: психологический анализ // Вестник Костромского Государственного университета. Серия: педагогика. Психология. Социокинетика, 2018. № 4. Т. 24. С. 98-101.

Баранова А.В., Яковлева Н.В. Анализ понятия «образ будущего» в контексте психологии здоровья // Личность в меняющемся мире: здоровье, адаптация, развитие, 2018. Т.6. № 4 (23). C. 808-822. DOI:10.23888/humJ20184808-822

Бовина И.Б. Социальная психология здоровья и болезни. М.: Аспект Пресс, 2008. 264 с.

Бовина И.Б., Дворянчиков Н.В., Дани Л., Эм М.А., Милехин А.В., Гаямова С.Ю., Якушенко $A . B$. Здоровье в представлениях детей и подростков // Экспериментальная психология, 2018. T. 11. № 1. С. 61-74. doi:10.17759/exppsy.2018110104

Васильева Н.Ю. Развитие представления о здоровье и здоровом образе жизни в подростковом и юношеском возрасте // Известия Российского Государственного педагогического университета им. А.И. Герцена, 2010. № 125. С. 13-18.

Грошев И.В. Топография формирующегося психологического пространства внутренней картины здоровья/болезни: гендерный аспект // Мир психологии, 2009. № 1(57). С 64-78.

Ермакова E. E. Культура выбора медицинских систем для профилактики и лечения заболеваний детей дошкольного возраста: дизайн исследования // Медицинская антропология и биоэтика: Научный, образовательный, научно-популярный журнал. Электронное издание. 2018 № 2 (16). Доступ: https://journals.iea.ras.ru/medanthro/article/view/590 (Дата обращения 07.09.2021).

Казанская К.О., Мещеряков Б.Г. Концептуальные изменения в представлениях о здоровье и болезни у младших школьников // Культурно-историческая психология, 2012. № 3. С. 19-29.

Кириленко Е.И. Символическая диагностика (по материалам традиционной культуры русских) // Евразийское научное объединение, 2016. Т.1. № 7 (19). С. 53-54.

Колдман С.Д. Представления о формировании пола в медицинских источниках XIX - начала $\mathrm{XX}$ века и народной традиции. Медицинская антропология и биоэтика: Научный, образовательный, научно-популярный журнал. Электронное издание. 2019. № 1 (17). Доступ: https://journals.iea.ras.ru/medanthro/article/view/15 (Дата обращения 07.09.2021).

Котова С. А., Николаева Е.И. Особенности представлений младших школьников о здоровом и больном человеке // Герценовские чтения. Начальное образование, 2010. Т. 1. № 1. С. 111-118.

Милюкова O.В. Соотношение внутренней картины здоровья и внутренней картины болезни в структуре личности // Вестник Тверского государственного технического университета. Серия: науки об обществе и гуманитарные науки, 2020. № 2 (21). С. 56-64. 
Михель И.В. Антропология детского здоровья (для студентов педиатрических факультетов). Медицинская антропология и биоэтика: Научный, образовательный, научно-популярный журнал. Электронное издание. 2016. №2 (12). Доступ: https://journals.iea.ras.ru/medanthro/ article/view/542 (Дата обращения 07.09.2021).

Орлова М.М. Перцепция здоровья и болезни как выражение адаптационных стратегий // Известия Саратовского университета. Серия: Философия. Психология. Педагогика, 2010. № 1. T. 10. C. 87-91.

Паутова Н.И. Ответственность за здоровье и болезнь: ценностный подход // Вестник Санкт-Петербургского университета. Серия 12. Психология. Социология. Педагогика, 2015. № 1. C. 130-136.

Тишков B.A. Об антропологии жизненных смыслов // Новые российские гуманитарные исследования. Электронное издание. Доступ: http://www.nrgumis.ru/articles/2011/ , дата обращения: 03.12.2018.

Туркина В.Г., Вербина О.В. Концепт «здоровье» в философско-культурологической рефлексии // Наука. Искусство. Культура, 2019. № 4 (24). С. 23-45.

Тхостов А.Ш., Нелюбина А.С. Соотношение рационального и иррационального в обыденном сознании на примере представлений о болезни // Вестник Московского университета. Серия 14: Психология, 2009. № 1. С. 32-38.

Чернышова Л.В. Культурная информация в русском языке (на примере представлений о здоровье и болезни) // Весці БДПУ. Серыя 1. Педагогіка. Псіхалогія. Філалогія, 2012. № 4 (74). С. $63-67$.

\section{References}

Arzumanyan, O.V. 2018. Predstavleniya shkol'nikov o zdorov'ye i bolezni: psikhologicheskiy analiz [Schoolchildren's notions of health and illness: psychological analysis]. Vestnik Kostromskogo Gosudarstvennogo universiteta. Seriya: pedagogika. Psikhologiya. Sotsiokinetika 4: 98-101.

Baranova, A.V. and N.V. Yakovleva 2018. Analiz ponyatiya "obraz budushchego" v kontekste psikhologii zdorov'ya [Analysis of the concept "image of the future" in the context of health psychology]. Lichnost' $v$ menyayushchemsya mire: zdorov'ye, adaptatsiya, razvitiye 4: 808822. DOI:10.23888/humJ20184808-822

Bovina, I.B. 2008. Sotsial'naya psikhologiya zdorov'ya i bolezni [Social psychology of health and illness]. Moscow: Aspekt Press.

Bovina, I.B., N.V. Dvoryanchikov, L.Dani, M.A. Em, A.V. Milekhin, S.Yu. Gayamova and A.V. Yakushenko 2018. Zdorov'ye v predstavleniyakh detey i podrostkov [Health in the views of children and adolescents]. Eksperimental'naya psikhologiya 1: 61-74. DOI:10.17759/ exppsy.2018110104

Chernyshova, L.V. 2012. Kul'turnaya informatsiya v russkom yazyke (na primere predstavleniy o zdorov'ye i bolezni) [Cultural information in Russian (on the example of ideas about health and disease)]. Vesti BDPU. Series 1. Pedagogika. Psikhologíya. Filologiya 4: 63-67.

Groshev, I.V. 2009. Topografiya formiruyushchegosya psikhologicheskogo prostranstva vnutrenney kartiny zdorov'ya/bolezni: gendernyy aspekt [Topography of the emerging psychological space of the internal picture of health / illness: the gender aspect]. Mir psikhologii 1: 64-78.

Kazanskaya, K.O. and B.G. Meshcheryakov 2012. Kontseptual'nyye izmeneniya v predstavleniyakh o zdorov'ye i bolezni u mladshikh shkol'nikov [Conceptual changes in the notions of health and illness in primary schoolchildren]. Kul'turno-istoricheskaya psikhologiya 3: 19-29.

Kirilenko, Ye.I. 2016. Simvolicheskaya diagnostika (po materialam traditsionnoy kul'tury russkikh) [Symbolic diagnostics (based on the materials of the traditional culture of Russians)]. Yevraziyskoye nauchnoye ob"yedineniye 7: 53-54.

Koldman, S.D. 2019. Predstavleniya o formirovanii pola v meditsinskikh istochnikakh XIX nachala XX veka i narodnoy traditsii Meditsinskaya antropologiya i bioetika: Nauchnyy, 
obrazovatel'nyy, nauchno-populyarnyy zhurnal. Elektronnoye izdaniye [Ideas about gender formation in medical sources of the XIX - early XX centuries and folk tradition. In Medical anthropology and bioethics: Scientific, educational, popular science journal. Electronic edition 1. https://journals.iea.ras.ru/medanthro/article/view/15 (accessed 7.09.2021).

Kotova, S. A. and Ye.I. Nikolayeva 2010. Osobennosti predstavleniy mladshikh shkol'nikov o zdorovom i bol'nom cheloveke [Features of the ideas of younger schoolchildren about a healthy and sick person] Gertsenovskiye chteniya. Nachal'noye obrazovaniye 1: 111-118.

Mikhel', I.V. 2016. Antropologiya detskogo zdorov'ya (dlya studentov pediatricheskikh fakul'tetov) Meditsinskaya antropologiya i bioetika: Nauchnyy, obrazovatel'nyy, nauchno-populyarnyy zhurnal. Elektronnoye izdaniye [Anthropology of Child Health (for Pediatric Students). In Medical anthropology and bioethics: Scientific, educational, popular science journal. Electronic edition] 2. https://journals.iea.ras.ru/medanthro/article/view/542 Accessed 7.09.2021.

Milyukova, O.V. 2020. Sootnosheniye vnutrenney kartiny zdorov'ya i vnutrenney kartiny bolezni $\mathrm{v}$ strukture lichnosti [Correlation of the internal picture of health and the internal picture of the disease in the structure of personality] Vestnik Tverskogo gosudarstvennogo tekhnicheskogo universiteta. Seriya: nauki ob obshchestve i gumanitarnyye nauki 2: 56-64.

Orlova, M.M. 2010. Pertseptsiya zdorov'ya i bolezni kak vyrazheniye adaptatsionnykh strategiy [Perception of health and illness as an expression of adaptation strategies] Izvestiya Saratovskogo universiteta. Seriya: Filosofiya. Psikhologiya. Pedagogika 1: 87-91.

Pautova, N.I. 2015. Otvetstvennost' za zdorov'ye i bolezn': tsennostnyy podkhod [Responsibility for health and illness: value approach] Vestnik Sankt-Peterburgskogo universiteta. Series 12. Psikhologiya. Sotsiologiya. Pedagogika 1: 130-136.

Tishkov, V.A. 2011. Ob antropologii zhiznennykh smyslov Novyye rossiyskiye gumanitarnyye issledovaniya. Elektronnoye izdaniye [On the anthropology of life meanings. In New Russian humanitarian studies. Electronic edition]. http://www.nrgumis.ru/articles/2011/ Accessed 7.09.2021.

Tkhostov, A.Sh. and A.S. Nelyubina 2009. Sootnosheniye ratsional'nogo i irratsional'nogo $\mathrm{v}$ obydennom soznanii na primere predstavleniy o bolezni [The ratio of the rational and the irrational in everyday consciousness on the example of ideas about the disease]. Vestnik Moskovskogo universiteta. Series 14: Psikhologiya 1: 32-38.

Turkina, V.G. and O.V. Verbina 2019. Kontsept “zdorov'ye” v filosofsko-kul'turologicheskoy refleksii [The concept of "health" in philosophical and cultural reflection] Nauka. Iskusstvo. Kul'tura 4: 23-45.

Vasil'yeva, N.Yu. 2010. Razvitiye predstavleniya o zdorov'ye i zdorovom obraze zhizni $\mathrm{v}$ podrostkovom i yunosheskom vozraste [Development of the concept of health and a healthy lifestyle in adolescence and adolescence] Izvestiya Rossiyskogo Gosudarstvennogo pedagogicheskogo universiteta im. A.I. Gertsena 125: 13-18.

Yermakova, Ye. Ye. 2018. Kul'tura vybora meditsinskikh sistem dlya profilaktiki i lecheniya zabolevaniy detey doshkol'nogo vozrasta: dizayn issledovaniya. Meditsinskaya antropologiya i bioetika: Nauchnyy, obrazovatel'nyy, nauchno-populyarnyy zhurnal. Elektronnoye izdaniye [Culture of choosing medical systems for the prevention and treatment of diseases of preschool children: research design. In Medical anthropology and bioethics: Scientific, educational, popular science journal. Electronic edition] 2. https://journals.iea.ras.ru/medanthro/article/ view/590 Accessed 7.09.2021. 